where, owing to the discharge of hot sea-water from a power-station, the temperature of the water was many degrees higher than in the adjacent part of the English Channel. Monro felt some uncertainty whether the worms represented a species accidentally introduced on the bottom of a ship from a warmer climate, or whether the high temperature of the water had produced a neotenic race of a widely distributed species, Hydroides norvegica, showing well-marked differences in size and structural details from the typical form.

In one of his shorter papers Monro discussed the need for a re-classification of the Echiuroidea, and made some important proposals for the rearrangement and redefinition of the families and genera of that group. He was responsible for the reorganization of the starfish gallery of the Museum in 1928, and also rearranged the study collection of echinoderms in accordance with modern classification. Almost the whole of the "General Guide to the Exhibition Galleries", published by the Museum in 1931, was written by him. He edited, for publication by the Museum, a series of postcards dealing with the old herbal "Hortus Sanitatis", a task in which his considerable knowledge of medieval Latin proved of great value. One of his last official duties at the Museum was the preparation, jointly with the present writer, of a new "Collectors' Handbook" dealing with the collection and preservation of invertebrates other than insects. He wrote the section on Vermes in the "Standard Natural History" (1931), and articles on several groups of annelid worms in the Encyclopædia Britannica (14th edition). For about two years (1925-27) he was editor of the Museums Journal.

Soon after the outbreak of war, Monro's services were lent to the Ministry of Food, where he worked until his last illness. He had been seriously ill in 1935 , and had undergone a severe operation. From that illness he had never completely recovered, and a second operation was performed a few weeks before his death. He possessed great charm of personality and a very open and upright character. He was a pleasant colleague and a good-natured companion, with a strong sense of humour and an acute and well-informed mind. Somewhat of a rebel, from his school days, against convention and what he considered social injustice, he was also interested in many aspects of learning and the arts, and was a man of very considerable culture and wide reading. $\mathrm{He}$ had a great love and understanding of poetry, and was deeply interested in theology and metaphysical philosophy. He always took a great delight in intellectual discussion, and many, no doubt, will remember a lecture delivered by him at a summer school at Cambridge in 1939 on the relation between science and religion. It seems to have been a desire to understand the deeper mysteries and problems of life that urged him to the study of biological science, and the same desire that led him, when already in his thirties, to embrace Catholicism, to which he was a fervent convert. He was keenly interested in the Neo-scholastic philosophy and in foreign politics, and was for a time honorary secretary of the Catholic Council for International Relations.

Until his health became seriously impaired, Monro had unbounded vitality and love of life, and of the good things it had to offer. His recreations included walking, swimming, yachting, fishing, shooting and fencing. For some years he was a leading exponent of the épée, being once runner-up in the British championship and one of the British representatives in a European tournament at Le Touquet. But above all he loved the open country and the hills, and most of his holidays were spent in walking in the Lake District, in Wales or in the west of Ireland. As a boy he had spent a number of holidays in France, acquiring a fluent knowledge of the French language, and an affection for the country and its people which he never lost.

Monro was twice married; first, in 1917, to Pamela Gartside Tipping, by whom he had one son (a captain in the Gordon Highlanders, missing at Singapore), and secondly, in 1927, to Sheila Mary Anderson, who, with their two young sons, survives him.

H. A. BAYLIS.

DURING an acquaintance with Monro extending over some twenty years I have had, in common with many other zoologists, occasion to regard him with much gratitude, admiration and affection. In an era when good systematists are becoming lamentably scarce, Monro stood out as an example of the ideal systematic worker. His systematic knowledge of the Polychæta, in the first place, was wide, accurate and of an intelligent type, and coupled with the mass of detail at his finger-tips connected with the literature of the subject and the diagnostic features of the species contained in the group was a particularly useful acquaintance with their distribution and geographical relations.

Although dealing almost entirely with preserved material himself, Monro was always keenly interested in receiving news of the living animals and actively aware of the importance of their ecological relations. $\mathrm{He}$ was always thoroughly willing to assist ecologists by determining their material, and did it promptly and in the most helpful way. My personal gratitude to him was elicited by the assistance which he gave me in ecological work carried out during the Barrier Reef Expedition and during ten years of marine studies in South Africa. Among a group of systematists whose kind services made it possible to work out the results of these studies at all, Monro was outstanding as one of the most actively helpful : in fact, he was a member of that rather small class, the 'perfect systematists'. This was the more so because, as so many of his friends are aware, Monro was a personality of great liveliness apart from his official work altogether. Very widely read and capable of talking entertainingly and yet with balance on almost any subject, and possessed of abilities quite distinct from those required for his museum work, he was a very fully developed human being and a most welcome companion. T. A. Stephenson.

\section{Prof. Joseph Paczoski}

Joseph Paczoskr, professor of the University of Poznan (Poland), who died on February 14, was a distinguished taxonomist and the founder of a new branch of botany, phytosociology. We do not know all the details concerning the last period of his life under German occupation in Poland; one can imagine, however, how much he must have suffered. At the beginning of the War in Poland, immediately after Poznan had been occupied by German troops, nearly all the university professors were arrested there, they were deprived of all their personal possessions, deported to the so-called GeneralGouvernement and left to starve. This was also the fate of the 77-year-old Prof. Paczoski. 
Joseph Paczoski was born on December 8, 1864, in Bialogrodka (Wolhynia). He was educated at the Agricultural School in Human (Ukraine) and afterwards studied and was assistant under the well-known Prof. Schmalhausen at the University of Kief (188894). He then held successively various posts. $\mathrm{He}$ was custodian of the Botanical Garden of St. Petersburg (1894-95), assistant at the Agricultural College of Dublany near Lw6w (south-eastern Poland) (189597), director of the Natural History Museum at Cherson (Ukraine) (1907-20), founded by himself, director of the Steppes Preservation of Ascania Nova (192223). After the outbreak of revolution in Russia, Paczoski refused the very good facilities for scientific work offered him by the Soviet Government and left Russia for Poland. There he was appointed director of the National Park in Bialowieza (1923-28) consisting of primeval forest. At the same time he was professor of taxonomy and plant-geography at the University of Poznan. During about fifty strenuous years he published more than two hundred scientific papers and articles. These works have earned him a place among the best-known men of science in Europe.

When engaged in the study of the flora and of plant-geography he spent most of his time on excursions to many places ranging from the Baltic to the Adriatic Sea and eastwards to the Volga.

No other Polish botanist, and only a few from other countries, have succeeded in investigating such wide areas as Prof. Paczoski. He was considered to be the most outstanding investigator of the flora of south-eastern Europe. Prof. Paczoski was the originator of a new branch of botany, phytosociology. Until a few years ago men of science of western Europe had to refer in phytosociology to the treatise by M. R. Harper, "The New Science of Plant Sociology" (1917). Still more recently Russian botanists with their tremendous enthusiasm have occupied the first place in the development of phytosociology, after having rightly acknowledged the great merits of Prof. Paczoski, the Polish pioneer in this field (W. W. Alechin: "Wann und wo ist die Phytosoziologie entstanden ?", Botaniska Notiser, Lund, 1924). It is more than fifty years since Prof. Paczoski published his work "Stages in Flora Evolution" (Russian, Wiestnik Jestiestwoznanja, St. Petersburg, 1891). There he laid down the principal outlines of phytosociology so clearly that to-day nothing more can be added or abstracted from these. The term 'phytosociology' was used for the first time in his next work "The Social Life of Plants" (published in the Polish magazine Wszechswiat, Warsaw, 1896). By giving the outlines of and a name to the new science Prof. Paczoski deserves a permanent place in the history of phytosociology. As acknowledgment of his great merits, the Polish Botanical Society reprinted his "Social Life of Plants" in the "Biblioteka Botaniczna", vol. 2, Cracow, 1930, published in Polish and English. The term 'phytosociology' has been used by the following authors in chronological order: J. Paczoski in 1896, P. Krylow in 1898, W. Sukaczew in 1915, M. Harper (United States) in 1917, in Scandinavia and Western Europe in 1919.

Researches made in Bialowieza directed his attention to the relation between the number of trees and diameter of the trees at $1.3 \mathrm{~m}$. (to about $4 \mathrm{ft} .3 \mathrm{in}$.) in pure and mixed woods respectively. Paczoski's curves for the primeval and thinned forests are based on these measurements. These methods have been termed hy Paczoski "biological structure of forests".
After further investigation they will be of practical importance in forestry. Results have been published in the Polish Forestry Society's Journal Sylwan printed in Lwow, and in the standard work "Forest of Bialowieza". In 1930 Paczoski was sent by the University of Poznan to Yugoslavia and Bulgaria for special forest investigations. His very interesting results were published in Sylwan.

Prof. Paczoski's death is a serious loss not only to Polish science but also to the scientific community throughout the world.

S. B

\section{The Right Hon. Lord Glanely}

The Right Hon. Lord Glanely, whose death occurred on June 28 as a result of enemy action, was president of the Court of Governors of the University College of South Wales and Monmouthshire. A Cardiff shipping magnate and head of the Tatem Shipping Company, he had always maintained a special interest in University College, Cardiff. After the War of 1914-18, when a special appeal was launched for the completion of the buildings on the new site in Cathays Park, he made a magnificent donation of $£ 100,000$ to that fund. This was allocated to the provision of the "Tatem Chemical Laboratory" and to the erection of a wing of the College to be devoted to the study of agriculture, a subject in which the late Lord Glanely was specially interested. This wing now houses the Advisory Departments of Agricultural Zoology, Agricultural Botany and Veterinary Science. In 1930 Lord Glanely made a gift of $£ 2,000$ to found two scholarships in memory of his wife, to be awarded in the first place to the children of parents who are or have been employed at or about Cardiff Docks. In this way he indicated his special interest in the welfare of the workers in the industry from which he derived his fortune. At the time of his death Lord Glanely was serving his third five-year term of office as president of University College, Cardiff. The College mourns the loss of a generous benefactor whose sympathy for, and interest in, its progress had extended over twenty. five years, the most difficult and important in its history.

\section{WE regret to announce the following deaths :}

Prof. Raymond Dodge, emeritus professor of psychology at Yale University, member of the U.S. National Academy of Sciences and president in 1916-17 of the American Psychological Association, on April 8, aged seventy-one.

Mr. E. C. Groesbeck, metallurgist of the Division of Metallurgy of the U.S. Bureau of Standards, on May 8, aged sixty-one.

Mr. G. C. Lloyd, secretary of the Iron and Steel Institute during 1908-34, on July 10, aged eighty-one.

Mr. W. F. Reynolds, chief of the Section of Triangulation of the Division of Geodesy of the U.S. Coast and Geodetic Survey, on May 1, aged sixty-one.

Prof. John Harrison Skinner, professor of animal husbandry and dean emeritus of the School of Agriculture of Purdue University, on April 28, aged sixty-eight.

Prof. A. N. Talbot, professor of municipal and sanitary engineering in the University of Illinois, on April 3.

Prof. W. H. Young, F.R.S., formerly professor of mathematics in the University of Wales, aged seventy-eight. 